\title{
BANNER AND NAME BOARD (CASE STUDY IN PANGKALPINANG CITY, BANGKA BELITUNG ISLANDS)
}

\author{
Asyraf Suryadin ${ }^{1}$, Muhammad Iqbal Arrosyad ${ }^{1 *}$, Harun Joko Prayitno ${ }^{2}$ \\ ${ }^{1}$ STKIP Muhammadiyah Bangka Belitung, INDONESIA \\ ${ }^{2}$ Universitas Muhammadiyah Surakarta, INDONESIA
}

Received 10 November 2018 - Revised 5 February 2019 • Accepted 4 March 2019

\begin{abstract}
This study aims to explain the forms of banner errors and nameplate in the City of Pangkalpinang, Bangka Belitung Islands to find out the factors behind the occurrence of errors in the use of Indonesian in the fabric range and nameplate in the City of Pangkalpinang, Islands. Bangka Belitung. The method used in this research is qualitative descriptive method. The data collection technique used is the triangulation technique which consists of observation, documentation, and interviews. The subjects in this study were all fabric ranges and nameplate in the city of Pangkalpinang, Bangka Belitung Islands which experienced errors in writing with the use of Indonesian. The results of this study are: From this level can be given a detailed explanation, that the errors found that consist of the use of foreign languages or English as much as $48 \%$, as much as $8 \%$ of non-standard language, the use of abbreviated words $11 \%$, and the use of local languages $22 \%$, then the purpose of making it does not pay attention to the rules of writing. and almost all spandex fabric or nameplate no one gives input or criticism, it's just that there are some from the public who ask questions related to writing or related businesses.
\end{abstract}

Keywords: Banner and nameplate, Language Error, Case study.

\section{INTRODUCTION}

For the people of Indonesia, Indonesian is an important language to be mastered. The importance of the community to pay attention to Indonesian will result in the initial use of speech or behavior. The importance of Indonesian can be proven by how people use it in conversations with others. In Article 28 of Law No. 24 of 2009 concerning Flags, Languages, and Symbols of the Country, as well as the National Anthem. That Indonesian must be used in public banner, public facilities, banners, and other information tools that are public services.

Good language is the language used in its place according to who is speaking and with how the conditions are, as expressed [1], [2], and [3] A good language is an appropriate language based on the place of contact of the language, with whom the other person is speaking, and according to the topic of the conversation. Thus, language that knows the place and time to whom the other person is speaking and at

(C) 2019 by the authors; licensee PGSD UMP. This article is an open access article distributed under the terms and conditions of the Creative Commons Attribution License (http://creativecommons.org/licenses/by/4.0/). $\checkmark$ muhammad.iqbalarrosyad@stkipmbb.ac.id (*Correspondence) 
what time the language is used. In daily activities, national language is a good language to apply [4], but in language not only expressed in oral but also in writing, as expressed [5] and [6] the acquisition of vocabulary is essential for successful second language use and plays an important role in the formation of complete spoken and written texts.

Society has a close relationship with the use of language, discourse, and the use of language that illustrates the potential [7]. Communication has a variety of good ways to do such as how it is delivered, what is conveyed, through what, to whom, and what influence. As stated by Harold Lasswell (Effendy, 2005: 10), that a good way to explain communication is to answer the following questions: "Who says what in which channel to who with what effect" or "Who conveyed, what was conveyed, through what, to whom, and what was the effect."

The use of local language by Indonesian people has changed, some even think that using a foreign language feels better [8]. The use of foreign languages that are using English, the use of foreign languages that are also mixed with Indonesian is not right [9].

The use of language on information boards or span cloths and banner is a good informing for public [10]. Advertising on information boards and fabric ranges will continue to dispute and become a public concern [11]. While this form of advertising in modern times, with better and more efficient facilities, many people still use traditional advertising techniques, namely with signs and banners [12].

Placement of fabric in public places by the community is now a follow up to provide interesting information to the community [13]. Thus, the community prefers to use banner when delivering information quickly in a short time and cheap in terms of cost. As stated [14] in [15]. [16] that banners have a range of fabric containing slogans, propaganda, or news that the public needs to know. [17] Spread fabric is a promotional media that is incidental or temporary installation. This media is in the form of a rectangle with installation must follow the four ends and installation only one for each location point, [18] add writing that sets out the purpose of making the fabric.

The results of observations on January 17, 2018, on Jalan Melintang Kota Pangkalpinang, Island Bangka Belitung, there is a restaurant signboard that uses writing "Cheerful Kedai Kedai Masakan Vegetarian \& Non Vegetarian Maknyuss \& Penuh Cita Rasa". And "Hotel Mitra Garden", as well as the Party's Span Fabric bearing the language of the region "Men Ukan Kite Sape Agik Kalok Ukan Kinik Sebile Agik". From some of these observations, the people of Pangkalpinang City, Islands. There are still some people who do not understand the correct use of Indonesian to express their love for Indonesia in their own country .

To solve the problem and achieve the above objectives, this study uses the theory of language use error analysis. The correct use of language is what is expected by every language user. But on the contrary, mistakes used in language will result in various communication problems. Thus, to overcome the impact of the use of incorrect language on span cloths and nameplate, an analysis of the use of the Indonesian language is needed with a study entitled "Span Fabric and Signboard 
(Case Study in Pangkalpinang City, Kepulauan Bangka Belitung).

Achieving the discipline character of language use can be done by learning to understand the language itself [19]. With education, the basic needs that are necessary for all walks of life are focused on writing skills [20]. Indonesian is learning that studies the method of reading texts in the target language is the center of activity in language learning [21]. Thus the character of discipline in Indonesian language also emphasizes how education has ever been experienced by the community.

Actions on language related to elocutionary are presented in several types of speech acts, which are assertive, directive, commissive, expressive, and declarative [22]. Linguistic text can be applied to outdoor media, banners and other advertising media [23]. Good writing needs to pay attention to the correct rules [24] because it will affect the reader in terms of understanding [25].

The mistake that is often found in the use of language is the arrangement of sentences [26] the correct sentence must also have the purpose for whom the sentence was shown. [27]. Language is a form of symbolic communication. Humans need communication in their daily lifeto establish relationships with other humans in their environment [28] as human relationships with other humans there is reciprocity between the two as the desire or purpose of making the nameplate information.

The formulation of the problem in this studyare: 1) What are the forms of writing errors in span cloth and nameplate in Pangkalpinang City, Bangka Belitung Island? 2) What are the factors underlying the occurrence of errors in the use of Indonesian in the name plate and banner in Pangkalpinang City, Bangka Belitung Islands?

The purpose of this study is to find out the forms of writing errors in the span cloth and nameplate in the City of Pangkalpinang, Bangka Belitung Islands and to find out the factors underlying the occurrence of errors in the use of Indonesian on span cloth and nameplate in the City of Pangkalpinang, Kepulauan Bangka Belitung.

\section{MATERIAL AND METHODS}

\section{Methods}

The method used in this research is qualitative. Qualitative descriptive method is a method of inquiry aimed at solving problems based on existing conditions or what they are [29]. Thus all the descriptions and analyzes related to the use of Indonesian on the range of fabric and nameplate in the city of Pangkalpinang are based on the data available at the time of this research. Data collection techniques in this study are observation, documentation, and interview techniques. Data analysis techniques in this study are using content analysis techniques (content analysis), [30] and [31] expressing the symbolic meaning obscured in literary works.

\section{Instrument}

The conception test instrument that was developed to find out the clarity and clarity of the writing on the fabric range and nameplate was 4 items. The test items 
are used to select the type of language used and also the correctness of writing. Of the various types of languages and types of explanation, they will be explained in detail in the results and research. In addition to the instruments used to collect the language directions used, other instruments are also used such as structured interview instruments. Structured instruments are used to find out more deeply and extensively related to the writing that is on the fabric range and nameplate. So that will get detailed information from the data needed and can be made conclusions from this research.

\section{Procedures}

The descriptive research procedure is a step that is used to describe, interpret a phenomenon, for example, conditions or relationships that exist, opinions that develop, using scientific procedures to answer the problem. Thus, the authors assume that the descriptive research method is consistent with the research carried out by the author. Because in this study, the author tries to describe a problem or phenomenon contained in the Range Cloth and Nameplate (Case Study in the City of Pangkalpinang, Bangka Belitung Islands).

Data collection techniques in this study are observation, documentation, and interview techniques. Observations were made on the use of language on banners, banner, and other writing that functioned as a general communication tool. Documentation is done by taking a picture of a span cloth and signboard complete with the address and also the time of taking. Interviews were conducted with shop owners and business entities to obtain information about the causes of vocabulary errors, understanding, and levels of education on spelling, and terms on the signboard of the shop, hotel, foundation or business entity. Thus the researcher took a photo on a span cloth and a nameplate then recorded the writing and made a collection of data collection techniques and then reviewed it.

\section{Data Analysis}

To achieve the objectives of this study, researchers need to use the theory of error analysis on banner and nameplates in distric of Pangkalpinang. Data analysis techniques in this study are using content analysis techniques, [32] reveals the symbolic meaning of obscured in literary works. The intention is to express the message or the content of the meaning and values contained in the span cloth or banner that is the source of the research data. Ismawati [33] also states that content analysis is a research technique for making inferences by systematically and objectively identifying specific characteristics in a technology. The steps are as follows:

1. Check notes and photos of fabric ranges and banner to make sure there are language errors including spelling, diction, terms, phrases, and sentences.

2. Grouping data. The results of observations and documentation on fabric ranges and banner are collected in groups to facilitate analysis.

3. Analysing errors in the use of the Indonesian language on the fabric range and nameplate according to the aspect of error that appears with reference to the rules used as theory. 
The analysis is done by describing the deviation of the rules found on the fabric and the nameplate also reveals the causes of the deviation in question. Search for the causes of deviations of the rules taken by comparing aspects of deviations with the rules of language related to the problem. In addition to language attitudes, bilingualism, and socio-cultural community supported by the results of interviews with several shop owners or companies. The focus of this study is matters relating to spelling, terms, choice of words, phrase structure, and sentences and reasoning.

\section{RESULTS AND DISCUSSION}

\section{RESULTS}

Based on the stages of the research method used in this study, this section presents the results and discussion of the errors found in the span fabric and signboard in the city of Pangkalpinang and also presents what factors are behind the error.

1. Forms of Writing Errors in Banners and Nameplates in Pangkalpinang City, Bangka Belitung Islands

Writing sentences on span cloths and nameplates in the city of Pangkalpinang find various forms, characters, layouts, and languages used. These findings suggest that there is a need for deeper follow-up of diversity in the use of language. After collecting data, the differences in the writing of the orange cloth and the nameplate can be illustrated in the diagram below:

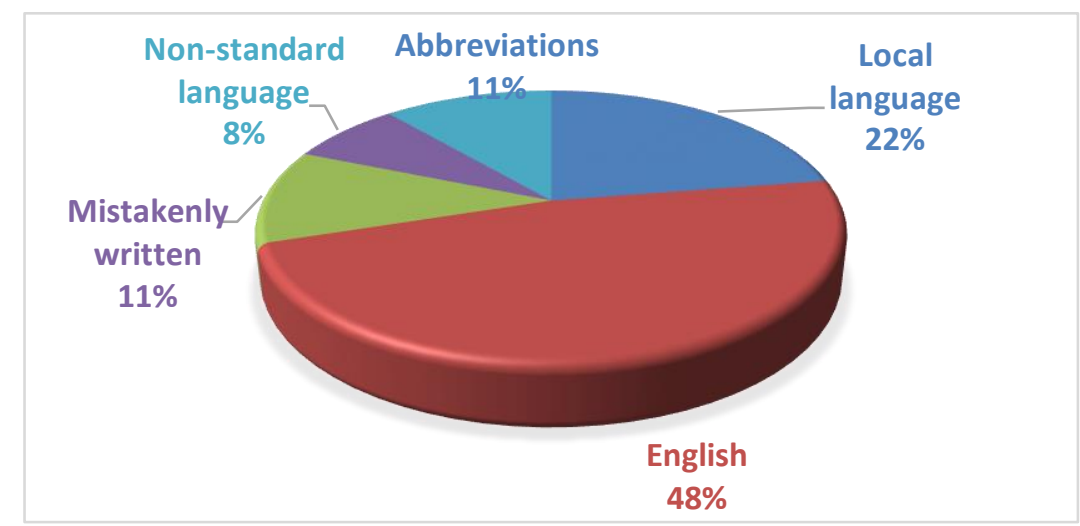

Figure 1 Level of Writing Error on Banner and Nameplate

Figure 1 shows the level of error in writing that is on a range of cloth and nameplate in a mixture in the city of Pangkalpinang. From this level can be given a detailed explanation, that the errors found that consist of the use of foreign languages or English as much as $48 \%$, as much as $8 \%$ of non-standard language, the use of abbreviated words $11 \%$, and the use of local languages $22 \%$. Calculations that have been made are the results of calculations from samples that have been taken in the city of Pangkalpinang with errors that dominate from each span fabric and nameplate.

The incorrect use of the Indonesian language on the fabric and the nameplate of Figure 1 which has been described in general will be explained in more detail to provide more clarity. 
a. Use of foreign languages or English

The use of foreign languages on information boards such as span cloth and signboards should not be used if it is not accompanied by the explanation below, the use of foreign languages is better avoided by the correct use of Indonesian. However, words or sentences in foreign languages can also be used if they are foreign branches and foreign names of trademarks that already have patents. See table 1

Table 1 Use of Foreign Languages in Banners and Nameplates

\begin{tabular}{ll}
\hline No & Sentence \\
\hline 1 & $\begin{array}{l}\text { ICC Ica Copy Camp, photo copy, jilid (sppiral.s/c. h/c), } \\
\text { laminating/press }\end{array}$ \\
\hline 2 & Royal Salad, creamy, fresh, healty \\
\hline 3 & $\begin{array}{l}\text { Baby and Kids Shop, menyediakan } \\
\text { pakaian/perlengkapan bayi \& anak-anak }\end{array}$ \\
\hline 4 & House of salsada \\
\hline 5 & Wat arun authentic thai tea \\
\hline 7 & $\begin{array}{l}\text { Ode's Shop, menjual: baju bayi/anak, alat rumah tangga, } \\
\text { handul, selimut, dll }\end{array}$ \\
\hline 8 & $\begin{array}{l}\text { Maryam_13 Cell, menjual, acc hp, pulsa hp, pulsa pln, } \\
\text { kartu paket. }\end{array}$ \\
\hline 10 & $\begin{array}{l}\text { Cheerful Kedai, kedai masakan vegetarian \& non } \\
\text { vegetarian, maknyuss \& penuh cita rasa }\end{array}$ \\
\hline 11 & $\begin{array}{l}\text { Digital Printing \& Advertising, solusi tepat media } \\
\text { promosi anda }\end{array}$ \\
\hline 12 & Wisata-Wisata dan Perjalanan (Tours $\mathcal{E}$ Travel) \\
\hline
\end{tabular}

Writing on span cloth and signboard with the use of a foreign language as shown in table 1 is writing that must not be used, that is, the mistake is that there are no supporting sentences from the main sentence so that it still raises questions, not italicized words that use foreign languages, and writings that use foreign languages not from foreign branches or foreign trademark names that already have patent. As said by [34] that the use of foreign languages should not be in any particular place in the territory of Indonesia because people must know various considerations, the word used is part of the original brand that is recognized by the advertising agency or the word from the branch of products outside Indonesia.

b. Non-standard word writing

Indonesian language writing must be in accordance with the writing rules set by the large Indonesian dictionary, so that if there is a composition of letters that are not appropriate then the word or sentence is considered wrong. As found in the writing of the banner and nameplate in Table 2.

\begin{tabular}{|l|l|}
$\begin{array}{l}\text { Table } 2 \text { Writing Nonstandard Words on } \\
\text { a Banner and Nameplate }\end{array}$ \\
\hline No & Sentence \\
\hline 1 & Apotik \\
\hline 2 & Kini \\
\hline 3 & fotocopy \\
\hline 4 & Sedia \\
\hline
\end{tabular}


The writing on the banners and name plate found does not use Indonesian words that are good and right. Discussing further about the non-standard use of Indonesian language in the fabric span and signboards, there need attention when making it for example: pharmacy that should be a pharmacy, now that should now, a photocopy that should be photocopied, who should provide, and kampong should be the village. This was also conveyed [35] that the use of language in the context of Indonesian must be in accordance with Indonesian rules in the form of standard Indonesian words.

c. Use of Abbreviations

The use of words or sentences with abbreviations, of course, if read by ordinary people or the general public certainly does not necessarily understand if there is no extension or meaning of the abbreviation. From the results of data collection, there are abbreviations that are not explained in the fabric range and nameplate.

Table 3 Use of Abbreviations in Banners and Nameplates
\begin{tabular}{cl}
\hline No & Sentence \\
\hline 1 & RM \\
\hline 2 & CV \\
\hline 3 & AD \\
\hline 4 & DBS \\
\hline 5 & ACC
\end{tabular}

Sentences abbreviations found are abbreviations in which the meaning of the abbreviation is not given. Explanation on the fabric and the nameplate must be given because not everyone understands the meaning of the word abbreviation. It was also conveyed by the Ministry of National Education [36] that word abbreviations can be used if there is an explanation in it so that the reader can understand the purpose of the abbreviation.

d. Use of Regional Languages

The use of language that is displayed for the common people in the country of Indonesia must, of course, be able to be understood for the Indonesian people themselves, so it does not use regional languages that can be understood by the people of the region itself. As found and can be seen in the following table.

Table 4: Use of Regional Languages in Banners and Nameplates

\begin{tabular}{ll}
\hline No & Sentence \\
\hline 1 & Mak Ngah \\
\hline 2 & Mpok kite \\
\hline 3 & $\begin{array}{l}\text { Mari kite, Men ukan kite sape agik kalok ukan kinik } \\
\text { sebile agik }\end{array}$ \\
\hline
\end{tabular}

The sentences used on range cloths and nameplate with the use of regional languages are not true if intended for all the general public, because it will not convey the message or the intent of making of the cloths and nameplate. Thus the sentence found is the wrong writing on the fabric range and nameplate.

2. The causal factors of errors of Errors in the Use of Indonesian Language on Banners and Nameplates in Pangkal Pinang City

The use of the Indonesian language in range cloth and signboard can be explainedregarding the writing in the cloth range and signboard itself in the city of 
Pangkalpinang. Based on interviews related to the understanding of the writing on the nameplate or on the fabric, the researcher can conclude that most of the fabric owners or the signboard understand or understand the meaning of the text listed so that the owner of the fabric and the nameplate can read as well can provide an explanation related to the writing on the fabric and the nameplate.

Based on the results of the most relevant interviews the level of education of the owner of the range cloth or signboard can be concluded by the writer, that the level of education available to banner owners is more on the bachelor degree, but there are also banner owners with high school and master background. Thus the whole of the owner of a banner of cloth or nameplate once occupied a school so that at least they can read and can understand the meaning of writing cloth or span cloth.

Furthermore, Almost all banners or signage are displayed, there is no input or criticism from the public, there are only a few from the community who ask questions related to writing. Thus the enthusiasm or interest of the community with banners and nameplates is still lacking.

\section{DISCUSSION}

Forms of Writing Error in Banners and Nameplates in Pangkalpinang City, Island Bangka Belitung that the form of mistakes that are often done is in writing sentences in foreign languages, the use of non-standard words, the use of abbreviated words that are not given an explanation, and the use of local languages. Hadi [37] revealed the use of language in writing there are provisions for the use of languages in public places, such as on signboards, span cloths, and billboards that are good and correct Indonesian.

The sentences used on range cloths and nameplate with the use of regional languages are not true if intended for all the general public, because it will not convey the message or the intent of making of the cloths and nameplate. Thus the sentence found is the wrong writing on the fabric range and nameplate. This was also conveyed by the Ministry of National Education [38] that the use of the Indonesian language must adjust the place and time accordingly.

Based on the results of the most relevant interviews the level of education of the owner of the range cloth or signboard can be concluded by the writer, that the level of education available to banner owners is more on the bachelor degree, but there are also banner owners with high school and master background. this was also conveyed [39] education would support the knowledge and experience of what was done, education would increase knowledge related to the language used.

\section{CONCLUSION}

Based on the research findings and conclusions of this journal, the following suggestions can be given, From this level can be given a detailed explanation, that the errors found that consist of the use of foreign languages or English as much as $48 \%$, as much as $8 \%$ of non-standard language, the use of abbreviated words $11 \%$, and the use of local languages $22 \%$, then the purpose of making it does not pay attention to 
the rules of writing. and almost all spandex fabric or nameplate no one gives input or criticism, it's just that there are some from the public who ask questions related to writing or related businesses.

\section{REFERENCES}

[1] Abdelrahman, M. S. H. B., \& Bsharah, M. S. (2014). The Effect of Speed Reading Strategies on Developing Reading Comprehension among the 2nd Secondary Students in English Language. English Language Teaching, 7(6), 168-174. , doi: 10.5539/elt.v7n6p168.

[2] Nunan, D. (2003). The impact of English as a global language on educational policies and practices in the Asia-Pacific Region. TESOL quarterly, 37(4), 589-613. doi: $10.2307 / 3588214$.

[3] Faisal, N., \& Talib, F. (2016). E-government to m-government: a study in a developing economy. Int. J. Mobile Communications, 14(6), 568-592. doi: 10.1504/IJMC.2016.079301.

[4] Hanson, M. J., \& McNamee, D. J. (2000). Efficient reading of papers in science and technology. On line], < http://www. cs. columbia. edu/ hgs/netbib/efficientReading. $p d f$.

[5] Al Qahtani, M. (2005). The use of vocabulary learning strategies by EFL learners at three different educational levels (Doctoral dissertation, University of Essex).

[6] Rodriguez, M., \& Sadowki, M. (2000). Effects of rote, context, keyword, and context/keyword methods on retention of vocabulary in EFL classrooms. Language learning, 50(2), 385-412. doi: 10.1111/0023-8333.00121.

[7] Holmes, J., \& Meyerhoff, M. (1999). The community of practice: Theories and methodologies in language and gender research. Language in society, 28(2), 173183. doi: $10.1017 / S 004740459900202 X$.

[8] Sari, B. T., Chasiotis, A., van de Vijver, F. J., \& Bender, M. (2019). We feel better when we speak common language; Affective well-being in bilingual adolescents from three ethnic groups in Indonesia. International Journal of Intercultural Relations, 71, 84-95. doi: 10.1016/j.ijintrel.2019.05.002.

[9] Machdalena, S. (2015). The Correlation between the Proper Name and Social Status in Russian and Indonesian Society. Procedia-Social and Behavioral Sciences, 200, 377-380. , doi: 10.1016/j.sbspro.2015.08.081.

[10] Francaviglia, N., Lombardo, A., \& Caramanna, S. (2013). Conservation work on an ancient Sicilian processional banner: preliminary analyses and in situ restoration. Procedia Chem, 8, 109-116. doi: 10.1016/j.proche.2013.03.015.

[11] Liu, C. W., Lo, S. K., Hsieh, A. Y., \& Hwang, Y. (2018). Effects of banner Ad shape and the schema creating process on consumer internet browsing behavior. Computers in Human Behavior, 86, 9-17. doi: 10.1016/j.chb.2018.04.034.

[12] Campbell, C., \& Evans, N. J. (2018). The role of a companion banner and sponsorship transparency in recognizing and evaluating article-style native advertising. Journal of Interactive Marketing,43, 17-32. doi: 10.1016/j.intmar.2018.02.002. 
[13] Handono, S. (2017). Implikatur Kampanye Politik dalam Kain Rentang di Ruang Publik. Aksara, 29(2), 253-266. doi: 10.29255/aksara.v29i2.52.253-266.

[14] Alwi, M., Kandavello, G., Choo, K. K., Aziz, B. A., Samion, H., \& Latiff, H. A. (2005). Risk factors for augmentation of the flow of blood to the lungs in pulmonary atresia with intact ventricular septum after radiofrequency valvotomy. Cardiology in the Young, 15(2), 141-147. doi: 10.1017/S1047951105000314.

[15] Goyena, R. (2019). Marketing Estrategico. Journal of Chemical Information and Modeling, 53(9), 1689-1699. doi: 10.1017/CBO9781107415324.004.

[16] Purnama, B. E. (2010). Pembangunan Sistem Informasi Pendataan Rakyat Miskin Untuk Program Beras Miskin (Raskin) Pada Desa Mantren Kecamatan Kebonagung Kabupaten Pacitan.Speed-Sentra Penelitian Engineering dan Edukasi, 2(4).

[17] Sari, I. P., \& Saputra, E. H. (2014). Sistem Informasi Raport Berbasis Web di SMP N 4 Temanggung. Data Manajemen dan Teknologi Informasi (DASI), 15(2), 24.l. Inf.

[18] Radjai, F., Delenne, J. Y., Azéma, E., \& Roux, S. (2012). Fabric evolution and accessible geometrical states in granular materials. Granular Matter, 14(2), 259264. , doi: 10.1007/s10035-012-0321-8.

[19] Chumdari, C., Anitah, S. A. S., Budiyono, B., \& Suryani, N. N. Implementation of Thematic Instructional Model in Elementary School. International Journal of Educational Research Review, 3(4), 23-31., doi: 10.24331/ijere.424241.

[20] Cahyono, B. Y. (2009). "the Teaching of Efl Listening in the Indonesian Context: the State of the Art," TEFLIN J., 20(2), 36-58, doi: 10.15639/teflinjournal.v20i2/194-211.

[21] Abdulhak, I. (2017). Implementation of scientific approach based learning. Int. J. Educ. Res, 5(8), 221-230.

[22] Askurny, N. R. (2018). “Political Campaign Language On The Outdoor Media : Is It A Register ?," vol. 4, no. 2,

[23] Poninthawong, C. (2012). Analysis of the Ambient Media Approach of Advertisement Samples from the Adman Awards and Symposium under the Category of Outdoor and Ambience. International Jour nal of Social, Behavioral, Educational, Economic, Business andlndustrial Engineering, 6(11), 3173-3176.

[24] Wicita, G. G. (2016). A Set of English Instructional Materials Using Task-Based Learning for News Production Management Study Program in STMM "MMMTC" Yogyakarta. LLT Journal: A Journal on Language and Language Teaching, 18(1), 63-73. doi: 10.24071/1lt.2015.180107.

[25] Martiarini, E. (2015). THE EFFECTS OF SPEED READING METHOD UPON STUDENTS'READING COMPREHENSION. DEIKSIS, 5(02), 89-105.

[26] Sari, N., Sumantri, M. S., \& Bachtiar, I. G. (2018). The Development of Science Teaching Materials Based on STEM to Increase Science Literacy Ability of Elementary School Students. Development. Int. J. Adv. Sci. Res. Eng., 4(7), 161-168, doi: 10.31695/ijasre.2018.32808.

[27] Indriawan, R., Slamet, A., \& Kardoyo, K. (2018). Implementation of Scientific Approach in Economic Learning. Journal of Economic Education, 7(1), 18-23., doi: 10.15294/jeec.v7i1.22418. 
[28] Sari, N., Sumantri, M. S., \& Bachtiar, I. G. (2019). The Development of Science Teaching Materials Based on STEM to Increase Science Literacy Ability of Elementary School Students. Development. Humanit. Soc. Sci. Rev., 7(2), 349-362, doi: 10.18510/hssr.2019.7241.

[29] Thorne, S. (2000). Data analysis in qualitative research. Evidence-based nursing, 3(3), 68-70.

[30] A. Suharsimi, Prosedur Penelitian : Suatu Pendekatan Praktik (Edisi Revisi). 2013.

[31] I. Articles, "International Journal of Active Learning," vol. 3, no. 2, pp. 116-123, 2018.

[32] Sumantri, B. (2011). Hubungan antara konsep diri dengan prestasi belajar pada mahasiswa pendidikan Ekonomi STKIP PGRI Ngawi. Media Prestasi, 8(2), 131143.

[33] Yuliana, R., \& Rimawati, Y. (2018). Adopsi IFRS dan Pengaruhnya Terhadap Manajemen Laba Akrual dan Manajemen Laba Riil Pada Perusahaan Manufaktur Di Bursa Efek Indonesia. InFestasi (Jurnal Bisnis dan Akuntansi), 14(1), 69-79..

[34] Spalart, P. R. (2009). Detached-eddy simulation. Annual review of fluid mechanics, 41, 181-202., doi: 10.1146/annurev.fluid.010908.165130.

[35] Tala, F. Z. (2016). "A Study of Stemming Effects on Information Retrieval in Bahasa Indonesia," M.Sc. Thesis, Append. D, 2003.

[36] Badan bahasa Kemdikbud, Pedoman Umum Ejaan Bahasa Indonesi. 2016.

[37] Hadi, H. A., \& Al Suwaidi, J. (2007). Endothelial dysfunction in diabetes mellitus. Vascular health and risk management, 3(6), 853., doi: 10.1055/s-2000-13206.

[38] Zainuddin, A., \& Al Sasongko, S. M. (2019). Bahasa Indonesia. DIELEKTRIKA, 6(1), 1-8., doi: 10.29303/dielektrika.v6i1.196.

[39] Agustina, E. S. (2017). Pembelajaran Bahasa Indonesia Berbasis Teks: Representasi Kurikulum 2013. Aksara, 18(1).

\section{http://jurnalnasional.ump/index.php/dinamika}

